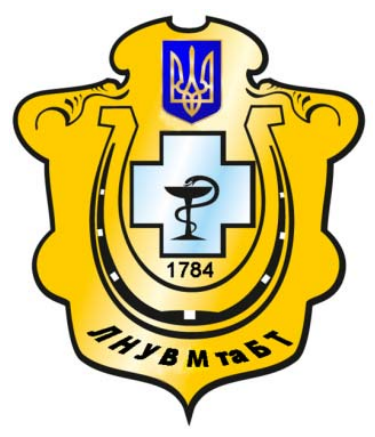

Науковий вісник Львівського національного університету ветеринарної медицини та біотехнологій імені С.3. Гжицького

Scientific Messenger of Lviv National University of Veterinary Medicine and Biotechnologies named after S.Z. Gzhytskyj

doi:10.15421/nvlvet7336

ISSN 2518-7554 print

ISSN 2518-1327 online

http://nvlvet.com.ua/

УДК 619:616.33:619:615.27:636.4

\title{
Вплив пробіотика та фітобіотика на показники Т- і В-клітинного імунітету відлучених поросят за гастроентериту незаразної етіології
}

\author{
Б.О. Лукащук \\ lukaw4yk@gmail.com
}

Львівський національний університет ветеринарної медицини та біотехнологій імені С. 3. Гжицького, вул. Пекарська, 50, м. Львів, 79010, Украӥна

\begin{abstract}
У статті представлений аналіз показників $T$ - $і$ В-клітинного імунітету відлучених поросят за гастроентериту незаразної етіології та після проведеного лікування з використанням пробіотика ТОЙОЦЕРІН $10^{9}$ та фітобіотика ЕКСТРАКТтм 6930 в складі основного рачіону у поєднанні з антибіотиком (10\% розчин енрофлоксацину гідрохлориду) в умовах сучасного свинокомплексу. Встановлено, щзо за гастроентериту в поросят після відлучення спостерігається зменшення показників $T$ i В-клітинного імунітету. Зокрема, в крові зменшується кількість загальних і активних T-лімфоциттів, T-хелеперів та Tсупресорів, а також кількість В-лімфоцитів, щз може вказувати на розвиток у поросят імунодефіцитного стану.

Відмічено позитивний вплив застосування пробіотика та фітобіотика в поєднанні з антибіотиком на Т-клітинну ланку імунітету поросят, на щьо вказує збільшення кількості загальних Т-лімфоцитів у крові до рівня показників клінічно здорових тварин. Таку тенденцію спостерігали щодо кількості Т-хелперів у крові, кількість яких була вищою у групах відлучених поросят яким додатково задавали пробіотик ТОЙОЦЕРІН $10^{9}$ та фітобіотик ЕКСТРАКТтм 6930. Встановлено позитивний вплив пробіотика та фітобіотика у поєднанні з антибіотиком на В-клітинний імунітет, на щзо вказує збільшення кількості В-лімфоцитів у крові поросят до рівня клінічно здорових тварин. Застосування пробіотика ТОЙОЦЕРІН $10^{9}$ та фітобіотика ЕКСТРАКТтм 6930 відлученим поросятам хворих гастроентеритом сприяє нормалізації кількості $T$ - $i$ В-лімфочитів, щзо є провідними імунокомпетентними клітинами крові, які характеризують рівень захисних сил організму тварин і стан специфічного імунітету.

Ключові слова: відлучені поросята, антибіотик, пробіотик, фітобіотик, гастроентерит, імунітет, T-лімфоцити, Tзагальні, Т-активні, Т-хелпери, Т-супресори, В-лімфоцити, імунорегуляторний індекс.
\end{abstract}

\section{Влияние пробиотика и фитобиотика на показатели Т- и В-клеточного иммунитета поросят-отьемышей при гастроэнтерите незаразной этиологии}

\author{
Б.А. Лукащук \\ lukaw4yk@gmail.com
}

Львовский национальный университет ветеринарной медицины и биотехнологий имени С.3. Гжицкого, ул. Пекарская, 50, г. Львов, 79010, Украина

В статье представлен анализ показателей $T$ - и В-клеточного иммунитета поросят-отьемылией при гастроэнтерите незаразной этиологии и после проведенного лечения с использованием пробиотика ТОЙОЦЕРИН $10{ }^{9}$ и фитобиотика ЭКСТРАКТТ 6930 в составе основного рациона в сочетании с антибиотиком (10\% раствор энрофлоксацина гидрохлорида) в условиях современного свинокомплекса. Установлено, что при гастроэнтерите в поросят после отъема наблюдается уменьшение показателей Т- и В-клеточного иммунитета. В частности, в крови уменьшается количество общих и активных Т-лимфоцитов, Т-хелеперов и T-супрессоров, а также количество В-лимфоцитов, что может указывать на развитие у поросят иммунодефиичита.

\section{Citation:}

Lukashchuk, B.O. (2017). Influence of probiotic and phytobiotic on parameters of T- and B-cell immunity in weaned piglets with non-contagious gastroenteritis. Scientific Messenger LNUVMBT named after S.Z. Gzhytskyj, 19(73), 173-177. 
Отмечено положительное влияние применения пробиотика и фитобиотика в сочетании с антибиотиком на Тклеточное звено иммунитета поросят, на что указывает увеличение количества общих Т-лимфоцитов в крови до уровня показателей клинически здоровых животных. Такую тенденцию наблюдали в отношении количества Т-хелперов в крови, количество которых было выше в группах поросят-отьемышей которым дополнительно скармливали пробиотик ТОЙОЦЕРИН $10^{9}$ и фитобиотик ЭКСТРАКТ тм 6930.

Установлено положительное влияние пробиотика и фитобиотика в сочетании с антибиотиком на В-клеточный иммунитет, на что указывает увеличение количества В-лимфочуитов в крови поросят до уровня клинически здоровых жсивотных. Применение пробиотика ТОЙОЦЕРИН $10^{9}$ и фитобиотика ЭКСТРАКТтм 6930 поросятам-отьемьишам больных гастроэнтеритом способствует нормализации количества T- и В-лимфоцитов, которые являются ведущими иммунокомпетентными клетками крови, характеризующче уровень защчитных сил организма животных и состояние специфического иммунитета.

Ключевые слова: поросята-отьемыии, антибиотик, пробиотик, фитобиотик, гастроэнтерит, иммунитет, Тлимфоцитыл, Т-общчие, Т-активные, Т-хелперы, Т-супрессоры, В-лимфоцитты, иммунорегуляторный индекс.

\title{
Influence of probiotic and phytobiotic on parameters of $T$ - and B-cell immunity in weaned piglets with non-contagious gastroenteritis
}

\author{
B.O. Lukashchuk \\ lukaw4yk@gmail.com

\begin{abstract}
Lviv National University of Veterinary Medicine and Biotechnologies named after S.Z. Gzhytskyi, Pekarska Str., 50, Lviv, 79010, Ukraine
\end{abstract}

In the use of colostral protective factors and insufficient activity of piglets immune system, against the background of immunodeficiency after weaning from sows developing diseases, often caused by conditionally-pathogenic or pathogenic microorganisms, including non-contagious gastroenteritis. The article presents analyzes of T-and B-cell immunity parameters in weaned piglets with non-contagious gastroenteritis and after their treatment with probiotic TOYOCERIN $10^{9}$ and phytobiotic EXTRACT ${ }^{\mathrm{TM}} 6930$ as part of the basic diet in combination with antibiotic (10\% solution of enrofloxacin hydrochloride) in the modern pig farm.

It was established that in piglets after weaning with non-contagious gastroenteritis decreased of T-and B-cell immunity parameters. In particular, in blood decreased number of total and active T-lymphocytes, T-helpers and T-suppressors also decreased number of B-lymphocytes, which may indicate the development in these immunodeficient condition.

It was established positive effect of probiotic and phytobiotic in combination with antibiotic on T-cell immunity of pigs, as indicated by the increased number of total T-lymphocytes in blood to the clinical healthy animals level. A similar tendency was observed in the number of T-helper cells, their number was higher in groups of weaned piglets which added probiotic TOYOCERIN $10^{9}$ and phytobiotic EXTRACT TM 6930. As to the immunoregulatory index, which is a quantitative ratio of T-helper to T-suppressor, there was no significant alteration of values in control and experimental groups of pigs. It was established positive effect of probiotic and phytobiotic in humoral immunity of piglets by increasing number of B-lymphocytes to the level of clinical healthy animals which indicate increased body ability to the active synthesis of protective antibodies. The use of probiotic TOYOCERIN $10^{9}$ and phytobiotic EXTRACT TM 6930 for weaned piglets with non-contagious gastroenteritis normalized number of T-and B-lymphocytes, which are the leading immunocompetent blood cells that characterize the level of animal body defense and condition of specific immunity.

Perspectives for further research will be directed at determining the therapeutic effectiveness of probiotic TOYOCERIN $10^{9}$ and phytobiotic EXTRACT TМ 6930 for weaned piglets with non-contagious gastroenteritis.

Key words: weaned piglets, antibiotic, probiotic, phytobiotic, gastroenteritis, immune system, T-lymphocytes, T-total, T-active, $T$ helper, T-suppressor, B-lymphocytes, immunoregulatory index.

\section{Ветуп}

Важливою умовою підтримання фізіологічного стану тварин $є$ ефективне функціонування імунної системи. Адже основна іiі роль зводиться до збереження стабільності внутрішнього середовища організму шляхом елімінації агентів, які несуть ознаки чужорідної інформації (Schubot and Tizard, 2004).

В онтогенезі поросят клітинна імунна реакція розвивається раніше ніж гуморальна. Адже основна маса лімфоцитів лімфовузлів, селезінки і крові - це Тлімфоцити, які $€$ ефекторами імунної відповіді на вплив різних вірусних, бактеріальних, грибкових та інших агентів.

Відомо, що у поросят до 30-денного віку завершується диференціація імунокомпетентних клітин (Т- і В-лімфоцитів) та формується основна маса плазмоцитів, здатних до активної продукції антитіл (Sinkora et al., 2002; Bulter et al., 2006; Salyga, 2009).
Тому, у процесі використання колостральних захисних факторів і через недостатню активність власної імунної системи, на фоні імунодефіциту внаслідок відлучення поросят від свиноматки виникають захворювання, найчастіше викликані умовно-патогенною або патогенною мікрофлорою, зокрема гастроентерити незаразної етіології (Karput' et al., 2005).

Відомі методи профілактики гастроентериту передбачають застосування хімічно синтезованих антибактеріальних препаратів, в тому числі кормових антибіотиків, які порушують мікробні екосистеми травного каналу та мають ряд негативних наслідків (Vondruskova et al., 2010; Kocjumbas et al., 2013).

Це спонукає фахівців до пошуку натуральних i безпечних засобів. Зокрема, сучасні господарства надають перевагу препаратам або кормовим добавкам, що містять у своєму складі природні біологічно активні компоненти: кормові дріжджі, бактеріїпробіонти, рослинні волокна, екстракти рослин, ефір- 
ні масла алкалоїди. Вони володіють антибактеріальними властивостями, створюють оптимальні умови для росту корисних біфідо- та лактобактерій кишечнику та пригнічують ріст патогенних мікроорганізмів, а також стимулюють імунітет (Yuan et al., 2006; Li et al., 2008; Ariza-Nieto et al., 2011; Kuz'menko and Chernjuk, 2012; Heo et al., 2012; Todoriuk et al., 2016).

Метою досліджень було визначити вплив пробіотика ТОЙОЦЕРІН $10^{9}$ та фітобіотика ЕКСТРАКТ 6930 у поєднанні з антибіотиком (10\% розчин енрофлоксацину гідрохлориду) на показники Т- i Bклітинного імунітету відлучених поросят за гастроентериту незаразної етіології.

\section{Матеріал і методи досліджень}

Дослідження проводилися в ПАП «Агропродсервіс» (Тернопільська область). Для дослідної роботи були відібрані чотири групи відлучених поросят (клінічно здорові, контрольна та дві дослідні, $\mathrm{n}=10$ ) породи Ландрас віком 30 діб за принципом аналогів.

Контрольна група - відлучені поросята хворі гастроентеритом незаразної етіології, яких лікували за схемою господарства (10\% розчин енрофлоксацину гідрохлориду, який вводили ін'єкційно в/м у дозі 1,0 мл/20 кг маси тіла тварини один раз на добу протягом 5 діб).

Перша дослідна група - хворі на гастроентерит поросята, яких лікували застосовуючи антибіотик (10\% розчин енрофлоксацину гідрохлориду) в такій самій дозі. Додатково застосовували пробіотик ТОЙОЦЕРІН $10^{9}$ (Ломанн Анімал Нутрішн, Німеччина) у дозі 500 г/т (згідно з настанови), який додавали до комбікорму протягом 5 діб.

Друга дослідна група - хворі на гастроентерит поросята, яких лікували застосовуючи антибіотик в такій самій дозі. Додатково застосовували фітобіотик ЕКСТРАКТ ${ }^{\mathrm{TM}} 6930$ (Панкосма С.А., Швейцарія) у дозі 150 г/т (згідно з настанови), який додавали до комбікорму протягом 5 діб.

Матеріалом для досліджень була кров відібрана 3 краніальної порожнистої вени до та після проведеного лікування. У стабілізованій гепарином крові поросят визначали загальну кількість Т-лімфоцитів (Е-РУЛ) за допомогою реакції спонтанного розеткоутворення 3 еритроцитами барана (Jondal et al., 1972), кількість активних Т-лімфоцитів (А-РУЛ) (Wansbrough-Jones et al., 1979), кількість субпопуляцій Т-лімфоцитів - Тхелперів (Тh-РУЛ) (Суровас В.М. с соавт., 1980), кількість Т-супресорів (Тs-РУЛ), шляхом віднімання від загальної кількості Т-лімфоцитів числа хелперів. Імунорегуляторний індекс (IPI) визначали за співвідношенням Т-хелперів до Т-супресорів. Кількість В-лімфоцитів (ЕАС-РУЛ) визначали в реакції комплементарного розеткоутворення 3 еритроцитами барана (Чернушенко Е.Ф. с соавт., 1979).
Контроль клінічного статусу поросят проводили щодобово впродовж дослідного періоду за загальноприйнятими методиками (Levchenko et al., 2005).

Отримані результати експериментальних досліджень були опрацьовані стандартними методами математичної статистики з використанням програмного забезпечення Microsoft Excel. Вірогідність показників оцінювали за критерієм Стьюдента.

\section{Результати та їх обговорення}

Перед початком лікування (табл.) статистично вірогідних різниць між показниками Т- і В-клітинного імунітету у крові хворих гастроентеритом поросят контрольної та дослідних груп не встановлено, проте в усіх тварин вони були вірогідно $(\mathrm{P}<0,001)$ меншими порівняно з показниками клінічно здорових, що може вказувати на виникнення у них імунодефіцитного стану (Karput' et al., 2005).

Встановлено, що після проведеного лікування кількість загальних Т-лімфоцитів у крові відлучених поросят контрольної групи вірогідно $(\mathrm{P}<0,001)$ збільшилась на 21,6\% (табл.). У першій та другій дослідній групах цей показник вірогідно (Р < 0,001) збільшився на 35,6 i 44,4\%, порівняно з показниками тварин до лікування, а також був вірогідно більшим на $8,4 \%(\mathrm{P}<0,05)$ та $14,6 \%$ ( $<<0,01)$ порівняно з показниками контрольної групи після лікування.

Таку тенденцію спостерігали щодо кількості активних Т-лімфоцитів у крові, кількість яких вірогідно збільшилась після проведеного лікування на 15,2\% ( $<<0,05), 28,1 \%(\mathrm{P}<0,01)$ і 33,1\% (P < 0,001), відповідно у всіх трьох групах порівняно з показниками до лікування.

Також спостерігали вірогідне збільшення кількості Т-хелперів у крові відлучених поросят контрольної та дослідних груп після лікування відповідно на 20,5\% $(\mathrm{P}<0,05), 38 \%(\mathrm{P}<0,001)$ і 44,8\% $(\mathrm{P}<0,001)$ порівняно до показників перед лікуванням (табл.). Подібну тенденцію спостерігали щодо Т-супресорів у крові, кількість яких вірогідно (Р < 0,001) збільшилась на 22,3, 32,3 та 42,6\% відповідно в трьох групах поросят. Проте кількість Т-хелперів і Т-супресорів у крові тварин другої дослідної групи було вірогідно більшою на $18,8 \%(\mathrm{P}<0,01)$ та 9,4\% ( $\mathrm{P}<0,05)$ порівняно 3 контрольною групою тварин і досягнула рівня показників клінічно здорових поросят.

Важливо зазначити, що кількість Т-активних лімфоцитів і Т-супресорів у крові поросят першої дослідної групи, а також Т-загальних, Т-активних лімфоцитів, Т-хелперів і Т-супресорів у другої дослідної групи нормалізувалася та досягнула рівня клінічно здорових поросят. Це вказує на стимулюючий вплив пробіотика ТОЙОЦЕРІН $10^{9}$ та фітобіотика ЕКСТРАКТ $^{\text {тм }} 6930$ на Т-клітинний імунітет.

Щодо імунорегуляторного індексу, який є кількісним співвідношенням Т-хелперів до Т-супресорів, то його значення не зазнавало вірогідних змін у контрольній та в дослідних групах поросят. 
Показники Т- і В-клітинного імунітету відлучених поросят за гастроентериту, $(\mathbf{M} \pm \mathbf{m}, \mathbf{n}=10)$

\begin{tabular}{|c|c|c|c|c|c|c|c|c|}
\hline \multirow{3}{*}{ Показник } & \multirow{3}{*}{$\begin{array}{c}\text { Біометри- } \\
\text { чний } \\
\text { показник }\end{array}$} & \multicolumn{7}{|c|}{ Група тварин } \\
\hline & & \multirow{2}{*}{$\begin{array}{c}\text { Клінічно } \\
\text { здорові }\end{array}$} & \multicolumn{2}{|c|}{ Контрольна } & \multicolumn{2}{|c|}{ Дослідна 1} & \multicolumn{2}{|c|}{ Дослідна 2} \\
\hline & & & $\begin{array}{c}\text { До } \\
\text { лікування }\end{array}$ & $\begin{array}{c}\text { Після } \\
\text { лікування }\end{array}$ & $\begin{array}{c}\text { До } \\
\text { лікування }\end{array}$ & $\begin{array}{c}\text { Після } \\
\text { лікування }\end{array}$ & $\begin{array}{c}\text { До } \\
\text { лікування }\end{array}$ & $\begin{array}{c}\text { Після } \\
\text { лікування }\end{array}$ \\
\hline \multirow{2}{*}{$\begin{array}{c}\text { Т-загальні, } \\
\text { \% }\end{array}$} & $\lim$ & $40,2-49,0$ & $26,7-37,1$ & $34,5-43,1$ & $25,6-36,7$ & $37,2-46,1$ & $26,4-36,9$ & $39,8-48,2$ \\
\hline & $\mathrm{M} \pm \mathrm{m}$ & $44,5 \pm 0,90$ & $\begin{array}{c}31,5 \pm 1,13 \\
\text { o০০ }\end{array}$ & $\begin{array}{c}38,3 \pm 0,96 \\
\text {,'ю0oo }\end{array}$ & $\begin{array}{c}30,6 \pm 1,14 \\
\text { ০০০ }\end{array}$ & $\begin{array}{c}41,5 \pm 0,89 \\
\text { /1'0* }\end{array}$ & $\begin{array}{c}30,4 \pm 1,06 \\
\text { ॰०० }\end{array}$ & $\begin{array}{c}43,9 \pm 1,03 \\
\text {, } 1 * *\end{array}$ \\
\hline \multirow[b]{2}{*}{ Т-активні, \% } & $\lim$ & $16,1-25,3$ & $11,5-18,1$ & $14,7-22,2$ & $12,4-17,9$ & $15,1-23,5$ & $11,9-18,3$ & $15,8-24,7$ \\
\hline & $\mathrm{M} \pm \mathrm{m}$ & $20,7 \pm 1,00$ & $\underset{\text { ॰০০ }}{15,1 \pm 0,60}$ & $\begin{array}{c}17,4 \pm \underset{\text { ○ }}{0,80} \\
0\end{array}$ & $\begin{array}{c}14,6 \pm 0,52 \\
\text { о०० }\end{array}$ & $\begin{array}{c}18,7 \pm 0,90 \\
\text { " }\end{array}$ & $\begin{array}{c}14,8 \pm 0,66 \\
\text { ॰०० }\end{array}$ & $\begin{array}{c}19,7 \pm 0,93 \\
\text { '"' }\end{array}$ \\
\hline \multirow{2}{*}{$\begin{array}{c}\text { Т-хелпери, } \\
\text { \% }\end{array}$} & $\lim$ & $23,5-30,8$ & $13,8-22,6$ & $17,8-26,5$ & $14,1-23,3$ & $20,7-28,6$ & $13,6-22,9$ & $22,8-30,5$ \\
\hline & $\mathrm{M} \pm \mathrm{m}$ & $27,6 \pm 0,73$ & $\begin{array}{c}18,5 \pm 0,86 \\
\text { ০০০ }\end{array}$ & $\begin{array}{c}22,3 \pm 0,93 \\
1000\end{array}$ & $\begin{array}{c}17,9 \pm 0,98 \\
\text { ০o০ }\end{array}$ & $\begin{array}{c}24,7 \pm 0,79 \\
\text { "1\% }\end{array}$ & $\begin{array}{c}18,3 \pm 0,91 \\
\text { ০০০ }\end{array}$ & $\begin{array}{c}26,5 \pm 0,75 \\
\prime \prime \prime * *\end{array}$ \\
\hline \multirow{2}{*}{$\begin{array}{c}\text { T-супресори, } \\
\text { \% }\end{array}$} & $\lim$ & $15,0-19,7$ & $10,3-14,5$ & $13,2-17,9$ & $11,5-14,8$ & $14,0-18,8$ & $10,7-14,0$ & $14,6-19,4$ \\
\hline & $\mathrm{M} \pm \mathrm{m}$ & $16,9 \pm 0,47$ & $\begin{array}{c}13,0 \pm 0,46 \\
\text { ০০০ }\end{array}$ & $\begin{array}{c}15,9 \pm 0,48 \\
\text {," }\end{array}$ & $\underset{\text { ০০০ }}{12,7 \pm 0,31}$ & $\begin{array}{c}16,8 \pm 0,48 \\
\text {," }\end{array}$ & $\begin{array}{c}12,2 \pm 0,30 \\
\text { ০o০ }\end{array}$ & $\begin{array}{c}17,4 \pm 0,43 \\
\prime \prime *\end{array}$ \\
\hline \multirow{2}{*}{ IPI } & $\lim$ & $1,3-1,9$ & $1,00-1,6$ & $1,0-1,8$ & $1,2-1,8$ & $1,2-1,8$ & $1,0-1,7$ & $1,3-1,8$ \\
\hline & $\mathrm{M} \pm \mathrm{m}$ & $1,6 \pm 0,06$ & $1,4 \pm 0,07^{\circ}$ & $1,4 \pm 0,08^{\circ}$ & $1,4 \pm 0,07^{\circ}$ & $1,5 \pm 0,06$ & $1,5 \pm 0,07$ & $1,5 \pm 0,05$ \\
\hline \multirow{2}{*}{$\begin{array}{c}\text { В- } \\
\text { лімфоцити, } \\
\%\end{array}$} & $\lim$ & $27,4-35,9$ & $15,1-26,1$ & $22,9-30,6$ & $16,0-25,7$ & $25,6-33,8$ & $15,6-26,4$ & $26,9-35,3$ \\
\hline & $\mathrm{M} \pm \mathrm{m}$ & $30,8 \pm 0,85$ & $\begin{array}{c}20,6 \pm 1,18 \\
\text { ০০০ }\end{array}$ & $\begin{array}{c}26,2 \pm 0,81 \\
\text {, }\end{array}$ & $\begin{array}{c}20,8 \pm 1,05 \\
\text { ০০০ }\end{array}$ & $\begin{array}{c}29,1 \pm 0,81 \\
\text { "’’* }\end{array}$ & $\begin{array}{c}20,0 \pm 1,28 \\
\text { ০o० }\end{array}$ & $\begin{array}{c}30,4 \pm 0,84 \\
\text { '"’** }\end{array}$ \\
\hline
\end{tabular}

Примітка: '-P<0,05; "- $P<0,01$, ,"- $P<0,001$, порівняно з поросятами до лікування

${ }_{-} P<0,05 ;{ }^{\circ}-P<0,01,{ }^{\circ}-P<0,001$, порівняно з клінічно здоровими поросятами

*-P $<0,05 ; * *-P<0,01$, порівняно з контрольною групою поросят після лікування

Встановлено, що кількість В-лімфоцитів у крові відлучених поросят контрольної, першої та другої дослідних груп після лікування вірогідно збільшилась на $27,2 \%(\mathrm{P}<0,01), 39,9 \%(\mathrm{P}<0,001)$ і 52,0\% (P $<0,001)$ порівняно 3 показниками до лікування (табл.). Проте їх кількість в першій та другій дослідних групах була вірогідно більшою порівняно 3 контрольною групою тварин на $11,1 \%(\mathrm{P}<0,05)$ та $16,0 \%$ (Р $<0,01)$ відповідно. Одержані дані вказують на позитивний вплив ТОЙОЦЕРІН $10^{9}$ і ЕКСТРАКТ 6930 на В-клітинну ланку імунітету, адже Влімфоцити є попередниками клітин, які продукують антитіла, а їх збільшення до рівня показників клінічно здорових поросят $€$ ознакою підвищеної здатності організму до активного синтезу захисних антитіл (Koval'chuk et al., 2009; Vishchur et al., 2015).

\section{Висновки}

1. Застосування відлученим поросятам дослідних груп пробіотика ТОЙОЦЕРІН $10^{9}$ та фітобіотика ЕКСТРАКТ $^{\text {Tм }} 6930$ сприяло стимуляції Т-клітинного імунітету, на що вказує збільшення кількості Тлімфоцитів та їх субпопуляцій у крові до рівня показників клінічно здорових тварин.

2. Встановлено позитивний вплив пробіотика та фітобіотика на гуморальну ланку імунітету поросят за рахунок збільшення кількості В-лімфоцитів у крові до рівня показників клінічно здорових тварин.

Перспективи подальших досліджень будуть спрямовані на визначення терапевтичної ефективності пробіотика ТОЙОЦЕРІН $10^{9}$ і фітобіотика ЕКСТРАКТ ${ }^{\mathrm{TM}} 6930$ за гастроентериту незаразної етіології відлучених поросят.

\section{Бібліографічні посилання}

Schubot, R.M., Tizard, I.R. (2004). Veterinary immunology: An Introduction. 7 th ed. - Philadelphia.

Salyga, N. (2009). Rozvytok imunnoi' systemy u porosjat. Visnyk L'vivs'kogo universytetu. Serija biologichna. 51, 3-14 (in Ukrainian).

Bulter, J., Sinkora, M., Wertz, N. (2006). Development of the neonatal $\mathrm{B}$ and $\mathrm{T}$ cell repertoire in swine: implications for comparative and veterinary immunology. Vet. Res. 37, 417-441.

Sinkora, J., Rehakova, Z., Sinkora, M. (2002). Early development of immune system in pigs. Vet. Immunol. Immunopathol. 87, 301-306.

Karput', I.M., Babina, M.P., Nikoladze, M.G., Babina, T.V. (2005). Diagnostika i profilaktika vozrastnyh i priobretennyh immunnyh deficitov. Vesci nacyjanal'naj akadjemii navuk Belarusi. Seryja agrarnih navuk. 1, 67-70 (in Russian).

Vondruskova, H., Slamova,R., Trckova, M. (2010). Alternatives to antibiotic growth promoters in prevention of diarrhoea in weaned piglets: a review. Veterinarni Medicina. 55(5), 199-224.

Vishchur, O.I., Gutyj, B.V., Hufrii, D.F. (2015). Imunnyi status, sposoby otsinky i metody korektsii u teliat rannoho viku: monohrafiia. Lviv: SPOLOM (in Ukrainian).

Kocjumbas, I.Ja., Gunchak, V.M., Stec'ko, T.I. (2013). Problemy vykorystannja antymikrobnyh preparativ dlja stymuljuvannja rostu produktyvnyh tvaryn ta al'ternatyvy i'h zastosuvannju. Naukovo-tehnichnyj bjuleten' Instytutu biologii' tvaryn i Derzhavnogo naukovo-doslidnogo kontrol'nogo instytutu vetpreparativ ta kormovyh dobavok. 14(3-4), 381-389 (in Ukrainian). 
Kuz'menko, O.A., Chernjuk, S.V. (2012). Vplyv prebiotyka ta kormovogo antybiotyka na imunologichni pokaznyky krovi ta mikrobnyj status travnogo kanalu svynej. Zbirnyk naukovyh prac' VNAU. 4(62), 10-14 (in Ukrainian).

Todoriuk, V.B., Gutyj, B.V., Khomyk, R.I., Vasiv, R.O. (2016). Influence of ferrovet $7.5 \%$ and ferosel $\mathrm{T}$ on the concentration of mineral substances in the blood serum of piglets suffering from Iron deficit anemia. Scientific Messenger LNUVMBT named after S.Z. Gzhytskyj. 18, 3(71), 139-143.

Ariza-Nieto, C., Bandrick, M., Baidoo, S.K. (2011). Effect of dietary supplementation of oregano essential oils to sows on colostrum and milk composition, growth pattern and immune status of suckling pigs. Journal of Animal Science. 89, 1079-1089.

Yuan, S.L., Piao, X.S., Li, D.F. (2006). Effects of dietary Astragalus polysaccharide on growth performance and immune function in weaned pigs. Animal Science. 62, 501-507.
Li, Z.J., Yi, G.F., Yin, J.D. (2008). Effects of organic acids on growth performance, gastrointestinal $\mathrm{pH}$, intestinal microbial populations and immune responses of weaned pigs. Asian-Australasian Journal of Animal Sciences. 21, 252-261.

Heo, J.M., Opapeju, F.O., Pluske, J.R., Kim, J.C. (2012). Gastrointestinal health and function in weaned pigs: a review of feeding strategies to control post-weaning diarrhoea without using in-feed antimicrobial compounds. Journal of Animal Physiology and Animal Nutrition. 97, 207-237.

Levchenko, V.I., Zajarnjuk, V.P., Papchenko, I.V. (2005). Hvoroby svynej: pidruchnyk. Bila Cerkva (in Ukrainian).

Koval'chuk, Ja.Ja., Vishhur, O.I., Vlizlo, V.V. (2009). T- i V-limfocyty krovi porosjat pry vidluchenni i'h vid svynomatok ta za umov zgodovuvannja biomasy drizhdzhiv Saccharomices cerevisia. Biologija tvaryn. 11(1/2), 287-292 (in Ukrainian).

Стаття надійшла до редакції 4.02.2017 